\title{
SENAM OTAK DALAM MENINGKATKAN PERKEMBANGAN KOGNITIF ANAK USIA DINI PADA KELOMPOK B DI KOBER QURROTU'AIN AL ISTIQOMAH
}

\author{
Yulianti ${ }^{1}$, Yanti ${ }^{2}$, \\ ${ }^{1}$ KoberQurrotu'ain Al Istiqomah, Cimahi \\ ${ }^{2}$ RA Sadarmanah, Cimahi \\ 1yuliantigunbat84@gmail.com, ${ }^{2}$ ulyanti@gmail.com
}

\begin{abstract}
Classroom learning is better if we can stimulate children according to the stage of child development. the development of the child among others is the development of moral, cognitive, language, emotional, social, motoric and artistic values. The child's cognitive development can be stimulated by the movement of brain exercises. Simple brain movement movement is identical to the movement touching certain parts of the body, so as to provide positive energies in the body of early childhood. Brain gymnastic activity is performed on the child's age because it requires an improvement in his cognitive abilities, such as completing tasks and responding to commands from his teacher. Early childhood is a child who has a very important age in improving cognitive development because of this period of time where brain development is very rapid. We carry out brain gymnastic activities aimed at improving cognitive development in KoberQurrotu'ain Al Istiqomah.
\end{abstract}

Keywords: cognitive development, brain gymnastics, early childhood.

\begin{abstract}
Abstrak
Pembelajaran di kelas lebih baik jika kita dapat menstimulus anak sesuai dengan tahapan perkembangan anak. Perkembangan anak diantaranya adalah perkembangan nilai agama moral, kognitif, bahasa, sosial emosional, fisik motorik dan seni. Perkembangan kognitif anak dapat distimulus dengan gerakan senam otak. Gerakan senam otak sederhana identik dengan gerakan menyentuh bagian-bagian tubuh tertentu, sehingga mampu memberikan energi-energi positif pada tubuh anak usia dini. Kegiatan senam otak dilaksanakan pada anak usia dikarenakan memerlukan peningkatan pada kemampuan kognitifnya, seperti menyelesaikan tugas dan menanggapi perintah dari gurunya. Anak usia dini merupakan anak yang memiliki usia yang sangat penting dalam peningkatan perkembangan kognitif karena masa ini masa dimana perkembangan otak sangatlah pesat. Kami melaksanakan kegiatan senam otak yang bertujuan untuk meningkatkan perkembangan kognitif di Kober Qurrotu'ain Al Istiqomah.
\end{abstract}

Kata Kunci :perkembangankognitif, senamotak, anakusiadini. 


\section{A. PENDAHULUAN}

Anak pra sekolah adalah anak yang berusia 0 lahir sampai berusia 6 tahun. Masa ini terdapat masa keemasan yaitu masa dimana anak mempunyai keistimewaan terhadap kemampuan dan kesehatan mereka. Jika masa ini dirangsang dengan baik maka tugas perkembangan mereka akan tercapai dan tidak akan terganggu. Menurut (Sujiono, 2012. Hlm. 6)Anak pra sekolah adalah anak yang sedang menjalani proses perkembangan dengan pesat dan fundamental bagi kehidupan selanjutnya.

Anak yang sehat harus memiliki pertumbuhan dan perkembangan yang baik. Pertumbuhan adalah berubahnya truktur tubuh seperti berat badan, tinggi badan, dan lingkar kepala, sedangkan perkembangan adalah perubahan fungsi tubuh dengan beberapa tugas perkembangan dan tahap perkembangan sesuai usianya.

Perkembangan anak yang harus tercapai diantaranya adalah perkembangan nilai agama dan moral, fisik motorik, bahasa, kognitif, sosial emosional serta seni. Dari beberapa perkembangan anak tersebut, perkembanga kognitif yang menonjolkan pengetahuan diri mengenai segala sesuatu yang didapat olehnya.

Perkembangan kognitif dapat dicapai dengan berbagai rangsangan baik oleh orang tua maupun guru. Perkembangan anak dapat melalui senam otak. Senam otak yang dapat menstimulus perkembangan kognitif melalui saklar otak, sehingga mengaktifkan energy positif pada anak prasekolah.

\section{B. KAJIAN TEORI DAN METODE}

Senam otak adalah suatu metode yang dilakukkan untuk mengoptimalkan fungsi otak(Dennison, Paul E \& Dennison, 2001). Senam otak dilakukan dengan gerakan tubuh tertentu sehinga menimbulkan rangsangan pada saraf dan sel otak. Senam otak merupakan program pelatihan yang dikembangkan oleh Paul E. Denisson dan Gail E. Denisson (1970). Program ini dibuat untuk mengatasi gangguan belajar pada anak-anak dan orang dewasa. Karena pada dasarnya, belajar adalah kegiatan alami dan menyenangkanyang dilakukakan sepanjang hidup.

Senam otak dilakukan agar orang yang sullit belajar akan berusaha keras dengan sekuat tenaga dan pikiran, sehingga mekanisme pada otak mengalami kelemahan dan pada otak-otak tertentu kurang berfungsi. Senam otak dapat meningkatkan kemampuan belajar dan bekerja karena dapat membuka bagian-bagian otak yang sebelumnya tertutup dan terhambat sehingga kegiatan bekerja/belajar berlangsung menggunakan seluruh otak (whole brain).akibatnya :

1. Emosi berkurang dan pikiran lebih jernih

2. Hubungan antara manusia dan suasana belajar/bekerja lebih rileks dan menyenagkan.

3. Kemampuan berbahasa dan daya ingat meningkat

4. Orang menjadi lebih bersemangat, lebih konsetrasi, lebih kreatif dan efisien.

5. Orang lebih sehat karena stres berkurang.

6. Prestasi belajar/ bekerja meningkat.

Senam otak merupakan sentuhan dan gerakan-gerakan yang bisa merangsang kerja dan berfungsinya otak secara optimal. Selain lebih bisa mengaktifkan kemampuan otak kiri dan otak kanan senam otak juga dapat menjembatani antara otak kanan dan otak kiri sehingga kerja sama bisa terjalin . senam otak dapat dilakukan oleh semua usia, sehingga ketika mengajarkan gerakan senam pada anak akan lebih mudah dan akan akan mamudah menerima pelajaran yang diajarkan, lebih bersemangat dan ceria menjalanii hari-harinya. Dengan rutinnya anak melakukan senam otak maka anak akan jauh dari kata stres, agresivitas dan hiperaktif. Gerakan dalam senam otak melatih otot-otot kecil yang melindungi syaraf-syaraf sehingga otak lebih mudah berkonsetrasi.

Agar berfungsi dengan optimal otak bisa diajak bersenam apalagi untuk anak yang mengalami kesulitan berkonsentrasi dalam belajar, tentu saja, gerakan yang dilkukan tidak boleh sembarangan. Karena senam otak adalah rangkaian gerakan yang dapat dilakukan untuk memperbaiki konsentrasi belajar si kecil, meningkatkan ras percaya diri, menguatkan 
motivasi belajar,serta mmebuat anak lebih mampu mengendalikan sters, maka latihan ini cocok untuk anak, terutama untuk menunjang belajar disekolah.

Ada beberapa manfaat yang apabila dilakukan berkala setiap hari yaitu:

1. Memungkinkan belajar dan bekerja tanpa stres.

Senam otak dapat membantu tubuh untuk merilekkan otot-otot tubuh sehingga kembali segar segar. Stres dipicu oleh terlalu banyaknya pekerjaan sedankan penyelesaiannya harus lebih cepat dan akurat, selain itu banyak hal yang dapat memicu stres baik dalam pekerjaan atau belajar

2. Meningkatkan kepercayaan diri

Dalam senam otak ada beberapa latihat yang dapat berdampak pada meningkatkan kepercayaan diri

3. Dapat menyikapi permasalahan dengan tenang Setiap orsng memilikki masalahnya masingmasing ada yang dapat menyikapinya dengan dengan tergesa-gesa, sambil marah, kalut dan lain sebagainya sehingga membuat masalah tidak terselesaikan,akan tetapi ada orang yang menyikapi masalah dengan tenag, santai,sambil memikirkan solusi yang baik dan tidak menimbullkan masalah lagi. Dua masalah tersebut tentu merukan dampak dari bagaiman orang menggunakan daya nalarnya . Senam otak, dapt membantu seseorang untuk memposisikan diri secara stabilapabila seseorang ada dalam masalah,

4. Bugar, sehat dan fit

Apabila seseorang melakukan senam otak setiap harinya dalam 10 menit maka otak akan seimbang sehingga berdampak pada mekanisme yang baik

5. Sebagai sarana untuk mencegah dan memudahkan penyembuhhan penyakit

Senam otak setiap harinya dalam 10 menit maka otak akan seimbang sehingga berdampak pada metabolisme tubuh dapat seimbang.

6. Mengaktifkan serta menyeimbagkan bagian otak kanan dan otak kiri

Menurut hasil penelitian Roger Sperry, mengatakan bahwa lapisan otak manusia terdiri dari bagian yaitu bekahan otak kanan dan otak kiri. Masing-masing memilikki fungsi meskipun tetap melakukan interaksi dan kerja sama yang solid di antara keduanya, otak kiri memainkan peran dalam aspek yang bersifat "akademis" dan logika.contohnya seperti logika matematika, katakata. Model pemikiran yang akurat, linear dan rasional.Sedangkan otak kanan memiliki fungsi untuk aktifitas yang kreatif seperti irama musik, gambar, dan imajinasi. Model berfikir acak, tidak teratur, holistik intuitif, dan imaginative. Otak kanan lebih mendorong manusia untuk bersikap kreatif alternatif dalam menyelesaikan masalah.

Kedua belahan otak kanan dan otak kiri di hubungkan melalui sistem jaringan yang di sebut corpus collasum yang merupaka sistem saklar yang melibatkan ratusan juta " kabel" neuro aktif. Secara fisiologis, corpus collasum berfungsi sebagai mediator pengiriman informasi antara bagian otak. Melalui mediator tersebut, otak dapat melakukan kerja sam dalam pengirriman informas, kolaborasi, dan integrasi.

\section{MEMULAI BRAIN GYM}

Menurut Asep Mahfudz (2017:14)Gerakan PACE dapat dilakukan dengan sebelum belajar dimulai, akan lebih baik, apabila gerakan PACE dikolaborasikan dengan materi pembelajaran yang sudah di pelajari. Manfaat melakukan kegiatan PACE sebelum pembelajar siswa dalam menyalakan otak terlebih dahulu sebelum melakukan kegiatan belajar.

Gerakan PACE terdiri dari gerakan senam

1. Minum air (drink water)

Air memiliki banyak fungsi dalam badan yang berfungsi untuk menunjang belajar anak. Diantaranya adalah darah lebih banyak untuk menerima zat asam yang di perlukan untuk belajar, melepas protein yang di perlkan untuk belajar hal baru, melarutkan garam yang mengoptimalkan energi listrik tubuh untuk membawa informasi ke otak, serta mengaktifkan sistem limpa.

2. Memiliki saklar otak (brain button)

Pijatan ini memiliki beberapa manfaat yakni mengkoordinasi bagian otak, meningkatkan keseimbangab badan, serta meningkatkan kerja sama antar kedua mata, sehingga dapat mengurangi kejulingan.

Memijat saklar otak adalah pijat lekukan di bawah tulang selangka, yakni di kiri dan kanan dari bidang dada. Sementara tangan lainnya menggosok daerah pusat. Sambal melakukan 


\section{JURNAL CERIA}

ISSN : 2614-6347 (Print) 2614-4107 (Online)

Vol.1 1 No.6 1 November 2018

latihan, gerakan mata ke atas bawah dan kiri kanan.

\section{Gerakan silang ( cross crawl)}

Menurut Dr.Denisson bahwa gerakan silang efektif karena dapat merangsang otak ki yang menerima informasi dan mengungkapkan, sehingga mempermudah proses belajar dengan keseluruhan otak dan bukamn dengan satu sisi saja pada satu saat diatur melalui pembaruanola lateralitas. Dalam latihan gerakan silang, anak dapat menggerakkan secara bergantian kaki dan tangan yang berlawanan, seperti geraka jalan di tempat.

a. langkah- langkah

1) Ambil posisi berdiri tegak

2) Kemudian, angkat kaki kiri dan sentuhlah lutut menggunakan tangan kanan, dan angkat kaki kanan dan sentuhlah lutut dengan tangan kiri

3) Lakukkan gerakan ini dengan semangat dan beberapa kali

b. Manfaat

Gerakan tersebut mampu mengaktifkan gerakan mata dari kiri ke kanan dan meningkatkan harmonisai penglihatan (binokular). Selain itu dapat mengaktfkan kemampuan akademik dalm mengeja, menulis,membaca serta mampu meningkatkan koordinasi kanan kir. Memperbaiki pernafasan, memperbaiki koordinasi dan kesadaran tentang ruang gerak, dan memperbaiki pendengaran dan penglihatan.

4. Kait relaks (hook up)

Latihan ini menghubungkan semua lingkungan fungsi bio listrik tubuh. Kekacauan aliran energy beredar dengan lancar di bagian tubuh yang tadinya tegang. Manfaatnya si kecil menjadi lebih percaya diri, dan perhatiannya akan lebih seksama. Gerakan menyentuh ujung-ujung jari tangan akan menyeimbangkan dan menghubungkan belahan otak. Ditambah dengan menempatkan lidah di langit-langit mulut., maka perhatian dipusatkan pada otak bagian tengah.

5. Pompa Betis

Gerakan pompa betis adalah suatu proses mengajarkan gerakan guna mengembalikan panjang alamiah dari tendon pada kaki dan tungkai bawah,. Pada saat merasakan bahaya, tendon memendek untuk menyiapkan gerakan lari yang dilepaskan dan otot akan kembali kepada ketegangan normal.

Langkah-langkah

a. Untuk melakukan gerakan pompa betis ini, berdiri dan letakkan tangan anda pada dinding atau sandaran kursi.

b. Tekuk kaki kanan ke depan, sementara kaki kiri diluruskan ke belakang dan punggubg membentuk sat ugaris lurus atau condongkan ke depan.

c. Angkat tumit kaki kiri diangkat dari lantai dan rasakan beban tubuh disangga oleh kaki kanan, dan sambi embuskan nafas perlahan-lahan.

d. Kemudian, tekan tumit kaki kiri ke lantai dan raskan beban tubuh sekarang disangga oleh kaki kiri embuskan nafas perlahan lahan.

e. Ulangi beberapa dan rasakan gerakan ini seolah-olah seperti sedang memompa betis. Semakin maju menekuk lutut ke depan maka peregangan otot di betis belakang akan lebih terasa.

f. Ulangi sebanyak tiga kali atau lebih kemudian ganti kaki.

\section{Manfaat}

Gerakan pompa betis adalah memberikan kemampuan untuk menahan dan memulai sendiri, menahan otot, mempertinggi kesadaran sikap tubuh dan ekspresi diri, maupun cara berbicara yang ekspresif dan kemampuan berbahasa.

6. Lambaian kaki (The Footlex)

Gerakan lambaian kaki seperti halnya gerakan pompa betis merupakan proses pengajaran kembali gerakan untuk mengembalikan panjang alamiah tendon pada kaki dan tungkai bawah. Tendon memendek untuk melindungi individu dari ancaman bahaya yang merupakan suatu respon yang disebabkan oleh reflex otak untuk mundur atau menahan. Dengan mempertahankan tendon betis di posisi yang memanjang sambal mengaktifkan atau melambaikan kaki, maka refleks penahan menjadi refleks.

Ada beberapa langkah-langkah gerakan lambaian kaki, diantaranya :

a. Siapkan kursi dan duduk dengan pergelangan kaki kanan diletakkan pada lutut kaki kiri. 
b.Sementara anda menempatkan ujung jari tangan kanan diletakkan bagian atas betis, sedangkan jari tangan kiri di betis kanan bawah.

c.Lalu, cari titik yang tegang pada otot betis, pergelangan kaki dan pada daerah belakang lutut kanan.

d.Kemudian tekan secara perlahan tempat yang sakit sampai terasa lembut dan lunak.

e.Ketika memegang titik tersebut, secara pelan dan teratur lambaikan kaki ke atas dank e bawah, dengan gerakan yang semakin luas dan mudah.

f.Selanjutnya gerakan diulang-ulang pada kaki yang lain.

Fungsi dari gerakan lambaian kaki adalah memberikan kemampuan untuk menahan atau memulai sendiri, menahan berat secara lebih baik, mempertinggi ekspresi diri, dan cara berbicara yang ekspresif ataupun keterampilan berbahasa.

Kemampuan akademik yang dapat dicapai :

a. Pemahaman sewaktu menyimak cerita

b. Kemampuan menulis kreatif

c. Kemampuan mengerjakan dan menyelesaikan tugas.

\section{Pasang kuda-kuda}

Gerakan pasang kuda-kuda adalah kegiatan gerakan meregangkan otot yang membuat rileks kelompok iliopsoas. Otot kelompok iliopsoas menegang gerakan dan kelenturan. Ketegangan pada pinggul menimbulkan kekakuan sacrum, memperpendek napas, dan mengganggu gerakan tulang kelapa. Kelompok otot iliopsoas adalah salah satu bagian terpenting tubuh karena berfungsi menstabikan dan merupakan kelompok otot dasara bagi tubuh yang kelenturannya penting bagi keseimbangan, koordinasi seluruh tubuh, dan focus tubuh. kuda-kuda :

Berikut langkah-langkah gerakan pasang

a. Berdirilah dengan tegak

b. Kemudian kaki dibuka dengan jarak lebih lebardarpada bahu.

c. Arahkan kaki kanan ke samping dan tekuk lutut, sedangkan kaki kiri tetap lurus, namun keduanya tetap di sat ugaris.

d. Embuskan nafas pada saat menekan lutut kaki kanan, kemudian luruskan kaki kanan dan Tarik pinggul ke atas sambal menarik nafas. e. Lakukan beberapa kali dengan posisi yang berbeda.

Gerakan pasang kuda-kuda dapat mengaktifkan otak untuk menyeberangi. Pada gerakan di atas dapat meningkatkan perkembangan kognitif.

Istilah kognitif berasal dari cognition yang berarti mengerti. Kognitif adalah proses terjadi secara internal di dalam pusat susunan saraf pasa waktu manusia berpikir (Gagne dalam Jamari, 2006).

Menurut para ahli jiwa aliran kognitifis, tingkah laku seseorang anak itu senantiasa didasarkan pada tindakan mengenal atau memikirkan situasi.

Teori perkembangan kognitif piaget menjelaskan anak dapat beradaptasi dan menginterpretasikan obyek serta kejadian kejadian di sekitanya. Piaget memandang bahwa anak berperan aktif dalam menyusun pengetahuannya mengenai sebenarnya. Anak mengenal melalui pengalamannya dengan dunia sekitar dia namun anak juga berperan aktif dalam menginterpretasikan informasi yang ia peroleh dari pengalaman serta dalam mengadaptasikan pada pengetahuannya yang telah ia kenal menurut Hetherington\&Parke,1975 (Jamaris, 2014).

\section{PEMBAHASAN}

A. Profil Lokasi Penelitian

a. Gambaran Umum Kober Qurrotu'ain Al Istiqomah

Kober Qurrotu'ain Al Istiqomah merupakan lembaga penyelenggara pendidikan anak usia dini jalur non formal dan tempat belajar alternatif bagi anak sebelum memasuki jenjang yang lebih tinggi dalam membantu orang tua membina dan menumbuhkembangkan kemampuan anak dalam pendidikan.

Kelompok Bermain Qurrotu'ain Al Istiqomah memiliki prinsip bermain sambil belajar dan membantu dalam mencapai tingkat perkembangan anak di sekelilingnya.

Salah satu langkah yang strategis dalam pembekalan anak yang optimal adalah didahului dengan pengenalan karakteristik dan tujuan pembelajaran yang akan diterapkan adalah pendidikan agama, moral, sosial, pengetahuan dan keterampilan dan kemampuan anak.

b. Tujuan Kober Qurrotu'ain Al Istiqomah 


\section{JURNAL CERIA}

ISSN : 2614-6347 (Print) 2614-4107 (Online)

Vol.1 1 No.6 1 November 2018

Dalam rangka memenuhi kebutuhan masyarakat khususnya anak-anak di bawah 6 tahun yang mencakup aspek kesehatan, gizi, pengasuhan, dan pendidikan dengan prinsip mudah, murah, dan bermutu, sehingga terwujudnya generasi muslim yang berkualitas dan berakhlak mulia.

c. Visi Misi Kober Qurrotu'ain Al Istiqomah Visi Kober Qurrotu'ain Al Istiqomah

“ Menyiapkan lembaga pendidikan prasekolah guna mewujudkan anak sholeh yang sehat, cerdas, ceria"

Misi

a. Membantu pertumbuhan dan perkembangan jasmani dan rohani agar memiliki kesiapan dalam memasuki pendidikan lebih lanjut.

b. Mengembangkan potensi yang dimiliki anak sesuai dengan tingkat pencapaian perkembangan anak usia dini

c. Mengajak orang tua untuk berperan aktif dalam merangsang perkembangan naka dengan aman, nyaman, dan menyenangkan

\section{d. Ruang Lingkup Kober Qurrotu'ain Al} Istiqomah

Kober Qurrotu'ain Al Istiqomah didirikan Tahun 2009 beralamat di Jalan Rancabali RT 02 RW 02, berdiri di atas lahan sebesar $435 \mathrm{~m} 2$ untuk kegiatan proses belajar dan mengajar, untuk area bermain Kober Qurrotu'ain Al Istiqomah mempunyai 3 kelas dengan luas $16 \mathrm{~m} 2$, serta area bermain yang cukup luas sehingga anak dapat bermain bebas mengapresiasikan kegiatannya di luar kelas, sebagai pedukung kegiatan belajar di luar kelas.

\section{B. Deskripsi Hasil Penelitian}

Penelitian ini diawali dengan kegiatan observasi awal dan wawancara dengan guru kelas Ceria di Kober Qurrotu'ain Al Istiqomah pada hari Rabu, tanggal 4 April 2018 pada semester dua tahun akademik 2017-2018. Hasil observasi awal dan wawancara, masalah yang dirasakan oleh guru tersebut adalah kesulitan dalam menerapkan Hasil wawancara yang kedua kalinya pada hari Jum'at guru dan peneliti telah menyutujui untuk menggunakan dalam kegiatan pembelajaran di kelas ceria dalam rangka mengatasi
Berdasarkan pertemuan selanjutnya guru dan peneliti, telah disepakati berdasarkan silabus pengajaran guru. Kemudian pada hari peneliti memperoleh izin dari kepala sekolah untuk melakukan penelitian di Kober Qurrotuain Al Istiqomah di kelas ceria yang didasari pertimbangan untuk mengatasi permasalahan guru yang bersangkutan dalam suatu pelaksanaan di kelas. Berikut gambaran umum lokasi penelitian :

Sebelum memasuki tahap pemberian tindakan, pada hari Kamis tanggal 5 April 2018 diadakan tes awal untuk mengetahui perkembangan moral kelas ceria. Guru beserta peneliti memberikan tes awal secara tertulis. Pelaksanaan tes menggunakan kegiatan awal, kegiatan inti dan akhir berlangsung dengan lancar dan terkendali. Secara sederhana, nilai awal diperlukan dalam pemberian tindakan pada setiap siklus yang direncanakan.

Oleh karena itu, dari nilai tes awal yang diperoleh menunjukkan bahwa nilai rata-rata masih kurang yaitu MB dari nilai maksimal yaitu BSB.

Pada hasil kegiatan senam otak di Kober Qurrotu'ain Al Istiqomah ini menyangkut peningkatan kemampuan kognitif dalam kegiatan sehari-hari, dalam beberapa pekan adalah sebagai berikut :

1. Pada awal pengenalan senam otak Brain Gym di Kober Qurrotu'ain Al Istiqomah, guru dan anak sangat antusias untuk mengetahui dan melakukan kegiatan tersebut. Jumlah anak didik pada Kober Qurrotu'ain Al Istiqomah adalah 46 orang dengan 3 rombongan belajar. Senam otak lebih dikhususkan pada rombongan belajar 5-6 tahun. Dengan jumlah laki-laki 9 perempuan 9 orang.

2. Senam otak mampu memberikan energy positif pada anak usia dini, dapat dibuktikan setelah melaksanakan kegiatan ini anak dapat lebih focus ketika diberikan tugas dan perintah oleh gurunya.

Keadaan relaks anak dapat lebih baik melakukan kegiatan senam otak, membuat lebih mudah untuk memberitahukan pembiasaan dan pengetahuan dalam pembelajaran. Selain itu saya memberitahukan makanan yang seimbang untuk mereka konsumsi yang dapat mempengaruhi 


\section{JURNAL CERIA}

ISSN : 2614-6347 (Print) 2614-4107 (Online)

Vol.1 No.6 1 November 2018

perkembangan otak serta konitif anak pra sekolah di Kober Qurrotu'ain Al Istiqomah.

\section{KESIMPULAN}

Berdasarkan dari kegiatan yang kami lakukan di Kober Qurrotu'ain Al Istiqomah dengan mencoba melaksanakan senam otak sederhana, maka kami dapat menyimpulkan bahwa perkembangan anak pra sekolah dapat kita stimulus dengan sebaikbaiknya dengan tepat.

Metode yang kita lakukan dapat dilaksanakan dimulai dari keluarga, lingkungan dan guru yang berada di sekolah. Setelah kondisi dan situasi keluarga mendukung $100 \%$, maka kita dapat mencari kegiatan yang menarik dan menyenangkan untuk anak salah satunya senam otak.

Adapun gerakan senam otak yang kita laksanakan sederhana saja yang terpenting dapat dilakukan di sekeloh sebbelum melakukan aktivitas atau pada saat pembelajaran.

\section{E. DAFTAR PUSTAKA}

Dennison, Paul E \& Dennison, G. E. (2001).

Brain Gym,. Jakarta: Grasindo.

Jamaris, M. (2014). Kesulitan Belajar. Bogor:

Ghalia Indonesia.

Sujiono, Y. N. (2012). Konsep Dasar Pendidikan

Anak Usia Dini. Jakarta: Indeks. 